\title{
The Witches of Hegel. On the Milky Origin of Evil*
}

\section{Las brujas de Hegel. Sobre el origen lácteo del mal}

\author{
FEDERICO RODRÍGUEZ GÓMEZ**
}

\begin{abstract}
This essay proposes a reading of the philosophical problem of evil in Derrida's works by calling attention to the figures of witch, cow and milk. I will follow this problem through his interpretations of Hegel, Nietzsche and Freud (especially as found in Glas [1974] and the unpublished seminar Manger l'autre [1989-90]). I first propose certain philosophical and psychoanalytic variations that aid in understanding a set of complicated crossreferences directly or indirectly established with Hamacher's works and the problem of eating (especially: Pleroma [1978]). Secondly, I show how the discussion of the problem of evil in these three figures can become a central locus for "deconstructive readings" (for readings that privilege a certain irreducible "complication" or "double-bind").
\end{abstract}

Keywords: Evil, Milk, Witch, Cow, Gift, Eating.

\section{Milky Ways}

\begin{abstract}
Resumen: Este artículo es una lectura del problema filosófico del mal a partir del estudio de las figuras de la bruja, la vaca y la leche en la obra de Derrida. Seguiremos los desarrollos que de este problema se encuentran en sus interpretaciones de Hegel, Nietzsche y Freud (especialmente, en Glas [1974] y en el seminario inédito Manger l'autre [1989-90]) proponiendo, en primer lugar, algunas variaciones filosóficas y psicoanalíticas para comprender un conjunto de intrincadas referencias cruzadas establecidas, directa e indirectamente, con el trabajo de Hamacher y el problema del comer (especialmente, en Pleroma [1978]) y, en segundo lugar, mostrando cómo la discusión sobre el significado de este problema del mal, desde las citadas figuras, se pudo convertir en un lugar de referencia para las "lecturas deconstructivas" (para lecturas que privilegian cierta "complicación" o "doble-bind" irreductible). Palabras claves: mal, leche, bruja, vaca, don y comer.
\end{abstract}

"Eine ganze Milchstraße von Einfällen". G. Chr. Lichtenberg.

"Aus deinen Giften brautest du dir deinen Balsam; deine Kuh Trübsal melktest du, -nun trinkst du die süsse Milch ihres Euters".

Fr. Nietzsche.

Fecha de envío: 25/03/2015. Fecha de aceptación: 21/07/2015.

* This work has been produced within the framework of the Postdoctoral Project FONDECYT number 3130345. I want to thank Mauro Senatore and Ronald Mendoza-de Jesús for their generous readings..

** Universidad de Chile, Postdoctoral fellow. E-mail: federico.rodriguez.gomez@gmail.com. Lines of research: Contemporary Philosophy (Phenomenology, Psychoanalysis, Critical Theory, Deconstruction). Recent publications: Cantos cabríos. Jacques Derrida, un bestiario filosófico (Santiago de Chile, Fondo de Cultura Económica, 2015); "Review", in Oxford Literary Review, vol. 37, n 1, 2015, pp. 157-161, "Freud's chows. On stupidity: a case study", in Revista de Filosofía: Aurora, Vol. 26, n 39, 2014, pp. 799-819. 
We must follow a long trace of milk, a whole "Milky Way" (cf. Derrida, 1978b, 167, $183,258)$, until we find the beautiful cow in Derrida's unpublished seminar from 1989-90, Manger l'autre. But when we reach the cow, we find not only milk-the nourishment par excellence of children. The history of milk and child development ${ }^{1}$, a history of feeding (breastfeeding), of eating-with others (sharing, partager) and of eating the other (sucking, absorbing) is also, on the one hand, a history of jealousies that originate around the division or the possession of the maternal breast or udder-the archi-genealogical demand of all psycho-analyses. On the other hand, in Derrida's cow we find a love story: bodies in communion, transactions from the outside to the inside, appropriations and expropriations. This history of jealousy and love is written in white. This white trail must be followed to avoid loosing track of what remains (reste), what may still remain. For you can never know with certainty what remains of an archi-originary scene, like the genetic motivations of nurturing. At the same time, we must continue without losing sight of a fine, but indelible trail of blood which reveals the great Derridean story of cruelty written in red. From white, white-scum, white-cream, white-meat, to red, and back again: in the movement from milk to blood ${ }^{2}$ there lies the hyperbolic outbreak of love, the in-ter-vention of sadism, the force of (primary) narcissism and its unlimited appetites.

When the dairy cow - the representation par excellence not so much of the mother as the desire for an origin, but rather of a supplementary wet nurse-appears in Derrida's seminar, its beauty is unrivaled by that of any other animal The cow appears at the end of the fifth session, and then again in the sixth and seventh sessions of Manger l'autre, at a moment when Derrida is wondering about "the proper" in regards to eating - "eating" as properly said, "eating properly." To do this, Derrida convokes, as he does so often, the ghost of incorporation (Ferenczi, Torok \& Abraham), which enters through the open mouth: that chaotic mouth ( $\chi \alpha$ ós, opening), a decisive point between inside and outside. A mouth that kisses, speaks, sucks, spits, bites and eats - a mouth whose functioning Derrida has spent so many decisive and beautiful pages analyzing, from the act of gobbling food, to the digestion and vomit of words. The cow's fresh milk would tell us something about the porosity, the essential instability, of the limits between nature and culture. For milk is pre-boiled inside the cow, as such, it is neither absolutely on the side of nature nor on the side of culture. In his reading of Vedic hymns in the seminar, milk appears for Derrida as crucial undecidable: it is at the same time raw and cooked. ${ }^{3}$ But he also says, as we will see, that milk is not just the

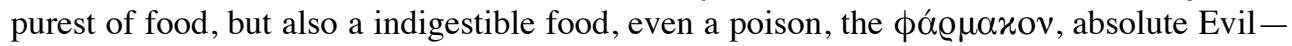
through, for example, the action at distance of witches, of old, dirty and vagabond women that unleash pure evil for evil's sake. This connection between milk as nourishment and milk as poison was already at work in Glas, in particular, in Derrida's reading of Jean Genet's Pompes funèbres, but also in his reading of Hegel. Glas's mise en scène of Genet's work with the death penalty, his figuration of the executioner and the scene of condemnation, insists

1 Through mothers or nurses, through original mothers or surrogate ones; because not only the father is a "legal fiction"-Joyce-, now more than ever the mother could also be one (cf. Derrida, 2001, 7-32).

2 The big story of the corporal liquids and liquors, internal and external, in Jacques Derrida — blood and milk, yes; but also semen, honey, tears, saliva, slime, sweat, etc.

3 This is a key problem already in the second part of De la grammatologie - the complication of the classical division by C. Lévi-Strauss or Rousseau (wet nurse). 
that falling is always falling away from an origin, from what is most familiar or closest, or safest. For example: a tit. And, however, a first question: isn't milk's exemplary instability, this contagious, contaminant undecidable element that nourishes and causes life to grow up and development of all the incoming, that is, all the monstrous? It remains to be seen. You have to go slower than ever: rumination is necessary. In any case, we should not forget, before I begin to develop all these connections, that for men as Clement of Alexandria, Irenaeus of Lyon and Augustine of Hippo blood and milk represents the passion of Christ and the doctrine of the Eucharist, the devouring of God (L. Charbonneau-Lassay). Sucking at a mother's breast is drinking the milk of God, the maternal womb as substitution of the original source of salvation (God's embodied word), a source of food and protection ${ }^{4}$. At a certain moment Derrida rescues the history of Catherine of Siena and the bleeding foreskin of Christ, but he will not touch the scene of the "heart-tit" - Sacred Heart - where the Saint is also protagonist according to the blessed Raymond of Capua (cf. Derrida, 1989, Box 20, Folder 2, Session 4; Box 20, Folder 3, Session 5; Derrida, 1991, § 13).

Before turning to the dairy cow of the 1989-1990 seminar, ${ }^{5}$ I begin with the first of the scenes announced: the milk, the lactic, the galactic ( $\gamma \alpha \lambda \alpha x \tau$ tıó $\varsigma$, milky), the "galactic segment" as in Glas (cf. Derrida, 1974, 177b). A cluster of symptomatic associations must be deployed first, so that we can begin to analyze the establishment and operation of certain values centered on milk-milk as venom, as nourishment, as the substitutive mother. For it is milk and the galactic law that inaugurate the mother (Derrida, 1974, 65-66b); and the mother herself is forever associated with a cow that is yet to come (à venir).

\section{Dialectic and galactic, or on the absent cow of Glas}

“Une dialectique d'un côté, une galactique de l'autre, hétérogènes et cependant indiscernables dans leurs effets, parfois jusqu'à l'hallucination".

Derrida, 1974, "Prière d'insérer".

If we start from the following lines, "et si je vous dis dès maintenant que le glas est une sorte de lait empoisonné...", we might reach the conclusion that the textual gaps in Glasabout which much has been written - are a deep pond that is neither full of salty water ${ }^{6}$ or fresh water ${ }^{7}$, but rather of corrupted milk ${ }^{8}$. These gaps are an unlimited reserve of infected food, a nourished soil that is regenerated in every reading, where everything from letters, metaphors, and devouring animals to absolute knowledge, floats, facing up, as if waiting to feast on the eyes of the unwary reader: "le pharmakon pénètre toujours comme le liquide, il se boit, s'absorbe, s'introduit à l'interior [...] le liquide est l'élément du pharmakon"

4 Virgo lactans - for example: Pedro Berruguete, 1465.

5 It will also appear, but mutilated, lame, milked in excess, weak, skinny, in a text that Derrida writes as an homage to Malamoud (cf. Derrida, 2002).

6 To which Derrida equally refers when he talks about the tears and, in different moments, the "goût de la mer" (cf. Derrida, 1989-1990, Box 20, Folder 1, Session 4).

7 We would have to pass across the bee's honey and also by some figs and grapes that arrive to the text from other places.

8 One of his youth's verses is repeated to us: "glu de l'étang lait de ma mort noyée". 
(Derrida, 1972, 175). Or, if you may, it is as if the textual white blank of Glas was the same milky way that I mentioned at the beginning, a way that links and condensates, that while feeding filters a big part of the writing work in the inventive heritage both of the Mallarmean's corpus and the Joycean corpus. Derrida doesn't quote any cows here in Glas, though in this text there are large amounts of milk, many breasts and many mothers. There is, however, a cow-boy: "fantôme de vacher" (1974, 218b). We have to drink from that white blank. We have to absorb it in such a way that the letters, the words, the phrases that are not there - but that in each moment aim to be "the phrase" that is missing-bundle up without space, as if they had soaked up the text's poison. Perhaps only then can we read other links that are there in the continuum of the text's variations.

This absence of the cow in Glas forces us to try to find it in other places, reaching beyond Glas's limits, moving to other "galaxies of events," as Joyce writes and as Derrida cites in his Ulysse gramophone (Derrida, 1987, 61). We should read this Joycean galaxy alongside the following passage from Genet "Aura-t-il éjaculé dans la galaxie? [...] 'éjacula une semence de constellations"” (Genet, 1951, 20). Between these two appearances of the galactic, milk-as a figure of nutrition - and the semen - as the image of fertility and dissemination - are mixed together (cf. Derrida, 1974, 128-129b: "voie lactée/voix lactée"). Derrida insists in Manger l'autre on this connection, as we shall see, through a reading of a Vedic hymn featuring Agni, the Vedic god. Agni rides a cow that he himself created, corrupted by desire, with the milk of the cow's udder being Agni's semen. Ever since Agni, we don't know what we drink when we drink. In any case, following Derrida's "La double séance," in commenting the text of Mallarmé one can read: "le SPERME, lave brûlante, lait, écume ou bave de la liqueur séminale" (Derrida, $1972,298)^{9}$. As I have been saying, the missing cow in Glas is to be found in Manger l'autre. I found it thanks to Werner Hamacher's Pleroma-zu Genesis und Struktur einer dialektischen Hermeneutik bei Hegel. Hamacher, a great reader of Derrida, mentions cows in this remarkable book on Hegel, published four years after Glas. He quotes Derrida's text several times. And he refers both to the milk, to the nutritional element, and to rumination, as an important part of the digestive process. Derrida also deal with rumination in Manger l'autre by following a very similar network of references ${ }^{10}$. Pleroma is an impressive reading of the writings of the young Hegel; particularly Der Geist des Christentums und sein Schicksal. Hamacher's book is strongly linked to Glas ${ }^{11}$ and, in particular, to the psychoanalytical armature that Derrida deploys on Hegel's back, although through an engagement with Hegel's own corpus. Pleroma is in a certain way a twin and little brother-inventive heir-to Glas. Both are fed from the same food source, although Pleroma certainly much more than Glas: the young Hegel. As if Derrida and Hamacher were sucking from the tits of Hegel. Sometimes it seems as though ${ }^{12}$, in reading Hegel, that Hamacher decoded and situated some of the keys condensed or omitted in Glas-developed from the absence, from elliptical procedures, from cuts and rewrites.

9 For these references see Bruchstück einer Hysterie-Analyse (1905) and Eine Kindheitserinnerung des Leonardo da Vinci (1910), where Freud links the udder-nipple of the cow with the phallus.

10 Nietzsche, digestion and eternal return of the same in Also sprach Zarathustra, a book where we find many references to udders and milk - and poison too.

11 This book also occasionally deals with the $\pi \lambda \dot{\eta} \varrho \omega \mu \alpha$ (cf. Derrida, 1974, 70).

12 Via Abraham and Torok-Hamacher was the translator of Cryptonymie: Le verbier de l'homme aux loups, published in 1979. 
But Pleroma makes its own way. Besides these friendly scenes of rewriting and moving ${ }^{13}$, Hamacher cites a disturbing scene from Hegel that is essential for our concern: the passage in the Vorlesungen über die Geschichte der Philosophie where witches corrupt milk. In Hegel's text these witches (Hexe, sourcière) reproduce evil by poisoning the milk, the symbol of the nourishment of Greece and of the Republic, a milk that is supposed to function as the originary source of nutrition for the development and growth of strong and healthy children:

Aber jene armen Weiber, die man Hexen nannte, sollten nur die Befriedigung einer kleinen Rache an ihrer Nachbarin gehabt haben, wenn sie der Kuh die Milch versetzten oder das Kind Krank machten. Man hat aber gegen sie nicht die Größe des Schadens beim Verderben der Milch oder Krankwerden des Kindes. Anschlag gebracht, sondern hat abstrakt die Macht des Bösen in ihnen verfolgt. (Hegel, 1975, 569) ${ }^{14}$.

Introducing psychoanalysis at this point of Hegel's text, Hamacher concludes that the witch figures in Hegel as the imago of the threatening mother (bedrohlichen Mutter). As noted by David Farrell Krell in his studies on German idealism and romanticism, Novalis and J. Brown establish a similar correlation between milk and venom, linking together milk to the question of the status of life-death (cf. Krell, 1998, 128). The uncanny image of the poisoned milk - "et si je vous dis dès maintenant que le glas est une sorte de lait empoisonné..."-can be found in Glas. And in Otobiographies, where Derrida says, referring to Nietzsche: "Ce qu'il a légué, en son nom, ressemble comme tout legs (entendez ce mot avec l'oreille que vous voudrez) à un lait empoisonné qui se mêlait d'avance [...] au pire de notre temps. Et ne s'y mêlait pas par hasard" (Derrida, 1984, 44). Nietzsche, Nietzsche's milk, is then a reference to be considered, although there is no explicit mark of this in Glas; but we won't see this until the end of the text.

We also find in Glas the image of the poisoned womb, "le sein tombe [...] Il s'empoisonne, devient agressif, châtre la castration"; and at the same time in a judas (peephole): "préférer le sein noir" (Derrida, 1974, 155b); Miracle de la rose. An image that also picks up the mother as a substitutive-mother-as wet nurse - and as a threatening-mother. In Jean Genet's Journal du voleur, a fundamental book for Glas, a dirty old woman lies at the center of the powerful scene with the robber's vaseline tube. ${ }^{15}$ Is there an explicit correlation between these issues? It is certainly not easy to prove. Perhaps, there is some form of solidarity between the old Genet and the infection of the milk in Glas via Hegel; between milk and false-mother, the false-mother and the executioner ${ }^{16}$. Hamacher, in a kind of wink to Derrida, expressly refers to the "miserly and dirty old woman" when he speaks of the etymology of

13 Derrida quotes Hamacher in a Nietzschean scene about vomit; scene that follows the cows in Pleroma (cf. Derrida, 1984, 82).

14 Just another image: "Denn vor 300 Jahren schien den Leuten nichts selbstverständlicher, als daß eine Hexe, wenn sie aufs Feld hinausgeht und die Hand gen Himmel erhebt, ein Hagelwetter auf das Getreide herabziehen könne, und daß sie mit einem Blick die Kühe behexen könne, so daß statt Milch aus den Euter Blut käme...”. (Benjamin, 1985, 148).

15 Sartre's lecture in the Saint Genet: “constellation of images” (Derrida, 1974, 181b).

16 Barber writes: "In his final year in Alligny, from the age of thirteen to fourteen, Genet was given a single duty by his foster family: each day he took the family's one cow out to a field beyond the village, spend the day there and returned with the cow in the evening". (Barber, 2004, 19). 
the word Hexe (witch). But he doesn't get this reference from Genet-in fact he doesn't quote Genet-but from J.C.V Schmidt's German dictionary, tracing a certain "etymological phantasy" concerning the origin of the name "witch" 17 . Of course, he could have also referred to many other dirty old women, but he doesn't do so. For example, he could have cited Kant in his "Reflexionen zur Anthropologie", about how old woman cause disgust (Weib Eckelt Alt), or Nietzsche's own description of truth in Die Wissenschaft fröhliche as an old woman ('die Wahrheit' hiess dies alte Weib...)" (cf. Menninghaus, 1999). Hamacher, I insist, wants to read the witch in Hegel himself, inside the Hegelian corpus: he wants to read the calamities of witches and their magic effects, to trace the fetish following Hegel himself (feitiço: spell, magic). So, we have a certain constellation: old woman, evil, milk, witch, disgust.

Already in Glas Derrida had quoted a fragment by Hegel on milk ( 373 , Enzyklopädie), enhancing its natural damaging power and awakening cannibal connotations: "le lait maternel, comme l'eau, se laisserait mal tolérer par l'adulte. C'est ce que dit Hegel. En toute logique, cela conduit à la nourriture carnée pour l'homme. Et même à l'anthropophagie: celle-ci est conceptuellement requise par l'idéalisme spéculatif. Il y culmine même à l'ouverture du Sa" (Derrida, 1974, 133a). While in Glas he doesn't quote the witches in Glas that Hamacher refers to in his reading of other other Hegelian fragments, he does make reference to the Portuguese origin of the word "fetish:" feitiço (cf. Derrida, 1974, 236a; Hegel, 1975, 156-157). For this reason, we should not exclude the possibility of reading, in Derrida's milk, this displacement. In fact, Glas's own movement invites this reading, since what immediately follows this passage in which Derrida cites Hegel's statement about milk as being potentially damaging to the adult is the emergence of poison (Gift), closely linked to the effect of an act of witchcraft. According to Hegel, witches poison cow's milk. Derrida again quotes Hegel: "Les médicaments [...] sont de nourritures différencies, mais totalement indigestes, négatives et étrangères. Ce sont des poisons" (Derrida, 1974, 133a). Should it be overlooked that bad milk, false milk or milk as a useless excess, milk as something that produces harm-mastitis, for example - in the other's body, has commonly been called in medicine since medieval times "witch's milk"? In France we can even find the expression: "être sorcière comme une vache" (PhilibertJoseph Le Roux, Dictionnaire comique, burlesque, libre, satirique, critique et proverbial..., 1750). But let's continue unfolding the knot of correlations, trying to shrink this swampy, sticky, field.

After all, this poisoned black milk ${ }^{18}$, and the breasts from which it springs, appear, by way of a cruel performativity - perverformativity: "Envois"-almost at the beginning of Glas: "Cela aurait commencé par empoisonner [...] Cela aurait donc pu commencer par l'empoisonnement parodique, altérant, pourrissant" (Derrida, 1974, 19b, 22b). In the peephole, the judas (19b), we can also read: "se laisser bercer, voire donner le sein par un bourreau". To give time, death, is to give the tit beyond all ontology: from breast to

17 Maybe we should remember this sentence, this biographical-scene: "Le dictionnaire disait, je cite: la mort s'appelle ainsi, parce elle mord amèrement. Derrida a été consterné, disant que cela ne pouvait être vrai, car ce n'était pas là l'étymologie correcte. C'est sûr, ai-je dit, c'est faux, et pourtant c'est ce qui était écrit" (cf. Hamacher, 2005, 58).

18 "Schwarze Milch“ (Celan), "lait du deuil” (Derrida, 1974, 225b), "larmes de lait” (Derrida 1974, 158b). 
being, to the breast of being in its French-German variations (the French sein and the German Sein $)^{19}$. The executioner-that is not, at least not specifically, a black breasted witch-adopts the figure of the milkman (cf. Derrida, 1974, 65b). This way, in grafting Genet in Hegel, Derrida decidedly poisons both the milk - which is itself indigestible to Hegel, as just quoted - and the flowers - those from rhetorics that already come from "La mythologie blanche" through a quote from Vorlesungen über die Ästhetik-and ends up with romanticism sensu lato. Indeed, what's interesting is that the milk is already itself, necessarily, a poison. Anyway, it shouldn't be forgotten that these beginnings are also almost parallel to a "Je commence par l'amour" [...] "ça commencerait par l'amour", that is the original reason for Derrida's decision about where to start his reading of Hegel: the problem of the family and, along with that, the problem of the mother. Poison, milk, breasts, love, executioner, mother, origin: the reasons that I was advancing are starting to unchain, little by little; but, in spite of so much love-Glas is, first of all, a book about/ of love, a monstrous love letter - we still have no cows or witches in Glas.

Derrida spoke about witches in "La pharmacie de Platon," a text published two years before giving the seminar that is going to be a large part of Glas (La famille de Hegel, 19711972). In fact, Socrates is defined as a sorcerer not only by Derrida, but also by Plato himself ${ }^{20}$. The witches are also at work in La Carte postale, in relation to Freud and to a discussion of what inaugurates and opens up: meta-psychological speculations. R. Gasché will explicitly deal with the Freudian witch in his 1974 article: "La sorcière métapsychologique" (Gasché, 1974, 83-122). Here, Gasché talks about Jenseits des Lustprinzips - a very important text for Derrida-as a conflict between the witch and the man of science. For Freud, it is necessary to let the witch play her part. In Freud, this connection between the witch and metapsychology is found in a well-known sentence from Die endliche und die unendliche Analyse (1937), which is a quotation of Goethe's Faust: "Man muß sich sagen: 'So muß denn doch die Hexe dran'. Die Hexe Metapsychologie nämlich” (Freud 1950, Bd. 16, 69). Derrida doesn't refer to this quote in La carte postale, but both the speculation ${ }^{21}$ and the demoniac - the being of the witchcraft-are recurrent themes and situations in this book. The witch appears many times in the first part, in the "Envois" (Derrida, 1980, 107, 267). Likewise, in Criptonymie. Le Verbier de l'homme aux loups (1976), Abraham and Torok write that nobody escapes the witch: "son cadrage est souverain".

In the seventies, the witch, the incarnation of the devil and of evil, flies not only above Derrida close to him. Someone might ask: does Hamacher echo the Socratic sorcerer of Derrida or the Freudian sorcerer when speaking of the Hegelian witches who poison the milk of the cows in Pleroma? Derrida had already talked about donation (poison/Gift: gift/ Gabe), which is the breastfeeding scene itself, in Donner le temps, but doesn't resort to any cow. Breastfeeding is fundamentally a gift of life, making the life of mammals flourish. The child - the republic or the church-receives the pure nourishment of the maternal breast. But the gift is not necessarily good. It could always be the case that what comes out of this could be "the worst [le pire]". That the ambivalence between gift and poison that persists in

19 "I am the breast [ich bin die Brust]", writes Freud (Freud, 1941, 151; cf. Hamacher 2006, 167-175).

20 "Socrate a souvent dans les dialogues de Platon le visage du pharmakeus" (Derrida, 1972, 136).

21 The metapsychology, the movement of witchcraft beyond the limits of science; the operation of the Freudian writing (cf. Derrida, 1980, 304). 
the Anglo-German couple: "gift/Gift" is highly significant. In the case at hand, the situation could be read like this: the milk in the mother's breast can always be poisonous, it can always be fatal to the growth and development of the child à venir. To give the breast is to give death. To give milk is to expose oneself to the possible outbreak of the worst where it is least expected, namely, in the mutual trust, in the most intimate confidentiality, of motherson relations ${ }^{22}$.

\section{Bovine-philosophy as philosophical vaccine: suck, chew, moo ${ }^{23}$}

As I have been saying since the beginning of this essay, the milky cow occupies a very important place in the unpublished seminary called Manger l'autre (1989-1990). In this case, the cow appears at the end of the fifth session (12-13-1989) after the name of Zarathustra, in a session that deals with Nietzsche's diverse and disseminated cows and with the problems at stake in any consideration of "milk and the milky." Derrida writes: "through the milk I get to the cow" (cf. Derrida, 1989-1990, Box 20, Folder 3, Session 6). Derrida dedicates the sixth session completely to the cow (1-10-1990) and he takes it up again in the seventh session of the seminar (01-17-1990). It is this cow that condenses in her udders that big mystery about "eating" and about "eating properly." What does it mean to eat? And what does it mean to eat properly? These are problems that occupy very important places in Derrida's work during the late 80 's, as testified by his interview with J.-L. Nancy, entitled "Il faut bien manger ou le calcul du sujet" (cf. Derrida, 1992, 269-301). In progressing from Hegel to Nietzsche, Derrida seems to be asking what does it mean to eat and what we do drink when we drink.

Manger l'autre is, to a large extent, a rereading of Glas. The seminar marks a moment where Derrida, fifteen years after the publication of Glas, comes back to his previous work and dedicates two years to it, touching on most of its motives - the rest, the Eucharist, the cannibalism, the introjection, etc.-while introducing some new ones. In general, the seminar re-elaborates what Derrida had said in many other texts since the 1970s: he takes up once more his readings of Hegel's and Novalis's philosophies of nature and the psychoanalyses of S. Freud, T. Ferenczi, K. Abraham, N. Abraham, M. Torok y M. Klein, paying close attention to the notion of the "metonymy of the introjection." For this reason, the seminar explicates-simultaneously and in an exemplary way-most of the gastronomic motives that have appeared in Derrida's work since his reading of Hegel in the 1970s. It is as if this Nietzschean cow from Manger l'autre had radio-controlled, through a sort of telepathy - the long-distance action of pathetism-all of Derrida work on "Hegel," on Hegel's poison and perhaps even Hamacher's work on Hegel's witches "Hexe ist ein anderer Name für Hegel" (Hamacher, 1978, 91). A nutritious cow, not just original-for we now see the proto-cow-but a teleological cow, one that marks the end without end of the incessant à venir of life.

22 So, there is nothing less safe than the adagio: "Vitam sugendo protraxi" (cf. Camporesi, 1993, 14; Huberman, 2013,35).

23 In Spanish the word "vacuna" can function as a noun (vaccine) or as an adjective (bovine): it is therefore a matter of imagining a potential "vacuna" philosophy (bovine philosophy) as a philosophical "vacuna" (philosophical vaccine). "Vacuno" is also the Spanish word for the grain or smallpox that appears on tits of cows. 
In the fifth session of Manger l'autre, Derrida himself refers to Glas and to the galactic logic he tries to display in this text. The psychoanalytic reference-the oral period as a pre-genital sexual organization, the question of cannibalism-imposes itself once more. Derrida had already explore this in a more explicitly biographic form when he addressed the role of milk in a discussion of Freud's legacy_lait/legs: these two words, milk/legacy, are pronounced the same in French - "the little Sigmund", that, according to what it's said through Jones, could have learned everything related with the maternal jealousy and the value of the milk through "our own experience": "le petit Sigmund avait été le seul détenteur de l'amour et du lait maternels, et l'expérience lui apprit alors quelle force peut avoir, chez un enfant, la jalousie" (Derrida, 1980, 356). Touching on these psychoanalytic questions, in the fourth session of the seminar (11-29-1989) Derrida reminds us that the first confession is the memory of a cannibal temptation, a cannibal memory, a desire for sarcofagia - this is nothing else but the memory of the breastfeeding (cf. Derrida, 1989-1990, Box 20, Folder 2, Session 4). It is in this precise moment that the problem of the mother and the son reemerges again in the seminar ${ }^{24}$, via the consumption of the mother thought breastfeeding. Just as in Glas, in the seminar, Derrida also explores the great issues of the brother's of jealousy - the proto-jealousy, as Derrida would say - surrounding the mother's breast. ${ }^{25}$ This jealousy has always been about the mother's milk: "Le lait, poison contre poison, est aussi traité comme la source de la jalousie" (cf. Derrida, 1974, 139b, 152b, 236-240a, 264a).

I expressly come back to the cow. As we have seen, in Glas, Derrida already said that the milk, Galactic law, inaugurates the mother, initiates her. Something similar happens here: it is milk again which turns the cow into the exemplary wet nurse. At the beginning of the sixth session of Manger l'autre, Derrida enumerates a series of famous cows: (1) "Nut", the Egyptian cow, sometimes represented in human form-as naked woman, whose body is drawn as a vault-sometimes with animal shape, carrying the Sun on its back; (2) "Auðumbla", the cow that was the companion of the giant Ymir, the proto-cow (Urkuh) from whose udder there flowed four rivers of milk that fed Ymir, a cow that licked ice and rocks and feed itself from salt; from there, as the Nordic legends say, the giant Buri would emerge, able to reproduce itself; (3) and "the cow of Agni", which I have already mentioned and which Derrida analyzes in a reading of a book from Charles Malamoud that interests him greatly-Cuire monde le monde. Rite et pensée dans l'Inde ancienne (1989). It's when he is referring to the cow Auðumbla and the cow of Agni that Derrida speaks of the cow as nourrice (nurse), as a "vache nourricière", perhaps in relation to the cow as a $\chi \omega$ @o $\alpha$-like figure $^{26}$. However, none of these cows was the first cow.

24 The sadistic temptation of the leech-kid: the appearance of milk tooth that threatens to rip off the nipple, a sudden transmutation of white to red.

25 Appropriation/expropriation: "processus désappropriant de la lactation" (Derrida, 1995, 37); in another sense: “dematernation", "méterpher" (cf. Hamacher, 1996: 89).

26 This is the determination that I have been tracking from De la grammatologie (Rousseau) and, later on, through the metamorphosis of the spider in Glas. The spider is fundamentally an evil replacement of the good mother. Abraham is the one who points out how the spider is not only bad-mother but, equally, the phallic mother, mother with manly sex, the sinister mother, the transvestite mother. But I can not go on with it, although I would have liked to explain exactly what happens when one is looking for a cow, "happy" to find a big nipple, when in fact it is a spider. I quote: "Nach Abraham 1922 ist die Spinne im Traum ein Symbol der 
In the context of the stories of these three cows, Derrida started this session of the seminar by quoting a fragment from A portrait of the Artist as a Young Man that appears in the very title of the session "Once upon a time and a very good time it was there was a moocow coming down along the road and this moocow that was coming down along the road met a nice little boy named baby tuckoo..." (Joyce, 1992, 7). Apart from the milk references I've mentioned, I don't know exactly why Derrida begins the session with this Joycean perversity. It is known that the cow plays a decisive role in A portrait. Through a complicated network of connections, the cow in Joyce's text recalls the mother: for Stephen Dedalus, the mother is a cow and the father a bird (cf. Curran, 1969, 163-170)27. On the other hand, in this text we also find references to the "Bous Stephanoumenos (Stephen's cow's soul)" and "Bous Sthephanephoros (cow adorned for the sacrifice; Bovфovı $\alpha$, death of the ox)", which reappear in Ulysses (cf. Gifford \& Seidman, 1988, 245), and which Derrida perhaps has in mind when he writes about the passage of cows (Bóojogos) in $L a$ contre-allée ${ }^{28}$.

In any case, the cow that interests Derrida the most is, as he said, the cow - not just one-of Also Sprach Zarathustra: the milk cows that Nietzsche picks on "the biggest gift made to humanity" (Ecce homo). Which cow/cows is/are we talking about exactly? Let's remember that this cow - and not just Hegel's - has been picked too by Hamacher in his Pleroma, a book that is apparently about Hegel, but that is also close to regurgitation of Nietzsche's cow. In the very beginning Derrida notes that he doesn't quite know what the cow "wants to say," its vouloir-dire or Bedeutung within Zarathustra's speech. Derrida takes a chance at this enigma, without any assurances, as if he were blind. Nietzsche himself uses the word "cow" in his writings to refer to: (1) G. Sand-that fruitful writing cow, (2) the Catholic religion-moral-cow and greasy happiness, (3) the perfect Buddhist, (4) the woman unable to feel friendship, (5) rumination as a process of lecture, (6) the city where Zarathustra preaches as he comes down from the mountains - the multicolored cow (die bunte Kuh), (7) the milk as the "to come" of life, etc., For Nietzsche, the cow remains undecidable, suspended in between affirmative and negative values. Just as its milk does. Derrida highlights four values in his reading of the cow in Also sprach Zarathustra. For the problems that I'm trying to deploy here, what looks more decisive is the fact that (1) Derrida notes how the cow's milk preserves its own venom, and, moreover, that (2) making milk into a venom foregrounds the question about the status of rumination. In this question there resonates Nietzsche's quote with which I opened this paper: "From your poisons you have extracted your balm; I've milked your melancholy cow, now drink the sweet milk from their udders".

(1) Given the circumstances, someone might wonder: is the poisoned milk of Glas also milk from Nietzsche's cow? Who is poisoning the milk in Glas, and how? Does the venom come from Genet? From Hegel and the witches of the Middle Ages? Yes, of course: there

Mutter, aber der phallischen Mutter, vor der man sich fürchtet, so daß die Angst vor der Spinne den Schrecken vor dem Mutterinzest und das Grauen vor dem weiblichen Genitale ausdrückt" (Freud, 1944, Bd 15, 25).

27 Stephen goes from loving to hating them, unable to look at the milk they give; later the beauty of the woman's breast is discussed, beauty in relation to future nutrition of offspring.

28 Joyce, in another reference, is quoted in parallel by C. Malabou. Derrida recovers this cow in the seventh session in order to speak of melancholy from Nietzsche's perspective. 


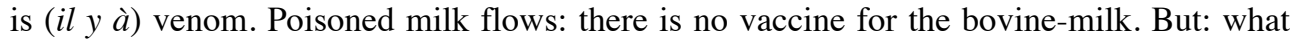
if Nietzsche's cow, Zarathustra's cow, was already at work in the poisoned milk of Glas? Nietzsche is in Glas: near the end of the book we can hear him in the $J a-J a$ of the ass, that brays without being there ${ }^{29}$. After this there are no more explicit references to Nietzsche, and therefore I can't prove my claim - but maybe this is ABSOLUTELY necessary para probar, to taste, "THE MILK". In any case, it is inside the cow where all these arguments will end up condensing, like curd, years later. I have already quoted this sentence of the Otobiographies ${ }^{30}$ that partially supports the claim that a poisonous cow was always already at work: "Ce qu'il a légué [Nietzsche, F.R.], en son nom, ressemble comme tout legs (entendez ce mot avec l'oreille que vous voudrez) à un lait empoisonné qui se mêlait d'avance [...] au pire de notre temps. Et ne s'y mêlait pas par hasard". This is certainly not just about Nietzsche, but Hamacher too: the one who reads all this from other angles, tracing many other variations - and who is quoted by Derrida himself. After developing some of these questions in the seminar's sixth session, Derrida reads Zarathustra in the seventh session, focusing on the following phrase: "Wunderliche Launen hat mein Hunger. Oft kommt er mir erst nach der Mahlzeit". He refers it back to his years-old analysis of "radical evil" as "structural perversion" and as the law of the gift (donation): there where a thing was expected to happen it is always possible that its opposite, the impossible, happens. I have already mentioned how the issue of the gift in Derrida, from the variability of the Gift/gift, is not just associated with good, but also with evil, and in particular, with the worst: the cow is not simply the good nurse, it may instead become the worst. Derrida recalls how "the last men" praised poison.

(2) Derrida as I have been insisting, is not only focused on the question of milk, not only on that of the poison; in addition, the question of rumination stands out in his commentary. He treats of it by spreading the same Latin root: rumen/ruminis (stomach); ruma/rumis (breast). Hamacher said it very well: "Kuh als nicht nur nehmen sondern auch Euter, widerkauen und sein und geben (Hamacher, 1978, 317)". Rumination is not a word strange in Derrida. Already in Éperons, when it is precisely Nietzsche that is being discussed, we find a rumination without cow, again the effect without a cause: "nécessité de lire Nietzsche en interrogeant sans cesse l'histoire de l'Occident, faute de quoi, surtout quand on prétend en finir avec séculaires illusions, on ne fait que ruminer des idées reçues et l'on est 'sans appel'" (Derrida, 1978a, 61). Rumination is not an interchangeable word here. It is not inexact to say that the rumination, rumination of thoughts, ruminating the history of philosophy as it is here, i.e., following what Nietzsche says in the prologue to Zur Genealogie der Moral ${ }^{31}$, or what is said in Also sprach Zarathustra ${ }^{32}$, is one of the most recognizable features of the Derridian philosophical exercise.

29 Nietzsche's name is not mentioned, only a quote, there's no ass but a bray, there's no cow but milk, in Glas - a game of the operant absence.

30 Extract of a seminary from de 1975 (La vie la mort), one year after Glas publication.

31 "Freilich thut, um dergestalt das Lesen als Kunst zu üben, Eins vor Allem noth, was heutzutage gerade am Besten verlernt worden ist - und darum hat es noch Zeit bis zur 'Lesbarkeit' meiner Schriften — zu dem man beinahe Kuh und jedenfalls nicht 'moderner Mensch' sein muss: das Wiederkäuen...” (Nietzsche, 1980 b, Bd. $\mathrm{V}, 13)$.

32 "An deren Worten will ich lange nun kauen gleich als an guten Körnern; klein soll mein Zahn sie mahlen und malmen, bis sie mir wie Milch in die Seele fliessen!” (Nietzsche, 1980a, Bd. IV, 328). 
Yes: Derrida, "patient as a cow", ruminates; philosophy is ruminated in their texts. Rumination: another name for deconstruction. There are already many. The mouth announces the ass (oral/anal) even as food convokes shit teleologically (cf. Derrida, 1990-1991, Box 20, Folder 13, Session 2). Artaud depicted this announcement in one of his drawings. Rumination: the eternal return of the same. Rumination, essential passivity: a double origin, a double fear, a double bind or complication, the law of all bovine philosophy as philosophical vaccine: the fear of being devoured, the fear of being poisoned. The milk-white will clear the wine-red: yes, but not the blood. Hexenglauben: "I can't do miracles [ich kann doch nicht hexen]", say as some Germans.

\section{References}

Barber, S. (2004), Jean Genet, London, Reaktion Books.

Benjamin, W. (1985), "Hexenprozesse", in Gesammelte Schriften, Bd. VII.1. Frankfurt am Main, Suhrkamp Verlag.

Camporesi, P. (1993), La vie del latte: dalla Padania alla steppa, Milan, Garzanti.

Curran, S. (1969), “'Bous Stephanoumenos': Joyce's Sacred Cow”, in James Joyce Quarterly, Vol. 6, No. 2 (Winter, 1969).

Derrida, J. (1972), La dissémination, Paris, Flammarion.

Derrida, J. (1974), Glas, Paris, Galilée.

Derrida, J. (1978a), Éperons. Les styles de Nietzsche, Paris, Flammarion.

Derrida, J. (1978b), La vérité en peinture, Paris, Flammarion.

Derrida, J. (1980), La carte postale. De Socrate à Freud et au-delà, Paris, Flammarion.

Derrida, J. (1984), Otobiographies, Paris, Galilée.

Derrida, J. (1987), Ulysse gramophone, Paris, Galilée.

Derrida, J. (1989-1990), Manger l'autre (Derrida Papers, MS-C01, Special Collections and Archives, The UC Irvine Libraries, Irvine, California).

Derrida, J. (1990-1991), Rhétorique du cannibalisme (Derrida Papers, MS-C01, Special Collections and Archives, The UC Irvine Libraries, Irvine, California).

Derrida, J. (1991), Circonfession, Paris, Seuil.

Derrida, J. (1992), “'Il faut bien manger' ou le calcul du sujet”, in Points de suspension. Entretiens, Paris, Galilée.

Derrida, J. (1995), “Avances”, in Margel, S., Le tombeau du dieu artisan, Paris, Minuit.

Derrida, J. (2001), “La Veilleuse”, in Trilling, J., James Joyce ou L'écriture matricide, Paris, Circe.

Derrida, J. (2002), "Reste - le maître, où le supplément d'infini”, in Bansat-Boudon, L., \& Scheid, J., (éds.), Le disciple et ses maîtres, Paris, Seuil.

Didi-Huberman, G. (2013), Blancs soucis, Paris, Éditions du Minuit.

Freud, S. (1944), Neue Folge der Vorlesungen zur Einführung in die Psychoanalyse, in Gesammelte Werke in Einzelbänden, Hrsg. von A. Freud, Bd. 15, Frankfurt am Main, S. Fischer.

Freud, S. (1950), Die endliche und die unendliche Analyse, in Gesammelte Werke, Bd. 16.

Freud, S. (1941), Ergebnisse, Ideen, Probleme (London, Juni, 1938), in Gesammelte Werke, Bd. 17. 
Gasché, R. (1974), "La sorcière métapsychologique”, in Digraphe, No. 3, 1974.

Genet, J. (1951), Notre-Dame-des-Fleurs, in Euvres complètes, vol II, Paris, Gallimard.

Gifford, D. \& Seidman, R. J., (1988), Ulysses Annoted. Notes for James Joyce's Ulysses, Berkeley \& Los Angeles, University of California Press.

Hamacher, W. (1978). Pleroma - zu Genesis und Struktur einer dialektischen Hermeneutik bei Hegel, in Hegel, G. W. F., Der Geist des Christentums, in Schriften 1796-1800, Berlin, Ullstein.

Hamacher, W. (1996), "Expositions of the Mother. A Quick Stroll through Various Museums", in: The End(s) of the Museum, Barcelona, Edicions de l'Eixample.

Hamacher, W. (2005), "Pour dire un mot, à la fin, pour commencer", trans.: Martin Ziegler, in Rue Descartes (Revue du Collège Internationale de Philosophie), No 48 ("Salut à Jacques Derrida"), April 2005.

Hamacher, W. (2006), “Anataxis. Komma. Balance. Anmerkungen zu Jean Daives W”, in Daive, J., Erzählung des Gleichgewichts 4: W. Basel, Urs Engeler Editor, pp. 167-175.

Hegel, G. W. F. (1969), Enzyklopädie der philosophischen Wissenschaften im Grundrisse, in Werke in 20 Bänden, Hrsg. v. E. Moldenhauer \& K. M. Michel, Bd. 8-10, Frankfurt am Main, Suhrkamp.

Hegel, G. W. F. (1975), Vorlesungen über die Philosophie der Geschichte, Stuttgart, Reclam. Joyce, J. (1992), A Portrait of the Artist as a Young Man, London, Penguin Books.

Krell, D. F. (1998), Sexuality, Disease, and Death in German Idealism and Romanticism, Bloomington \& Indianapolis, Indiana University Press.

Menninghaus, W. (1999), Ekel. Theorie und Geschichte einer starken Empfindung, Frankfurt a. M., Suhrkamp Verlag.

Nietzsche, F. (1980a), Also sprach Zarathustra. Ein Buch für Alle und Keinen, in Sämtliche Werke. Kritische Studienausgabe in 15 Banden (KSA), Hrsg. von Giorgio Colli \& M. Montinari, Bd. 4, München, Deutscher Taschenbuch Verlag.

Nietzsche, F. (1980b), Zur Genealogie der Moral: Eine Streitschrift, in KSA, Bd. 5.

Stark, T. (2004), "Even Better than a Cow, O Zarathustra!", in Acampora, C. D., \& Acampora, R. R., A Nietzschean Bestiary. Becoming Animal Beyond Docile and Brutal, Maryland, Rowman \& Littlefield Publishers. 
